\title{
Role of Caveolin I, E-Cadherin, Enolase 2 and PKCalpha on resistance to methotrexate in human HT29 colon cancer cells Elisabet Selga ${ }^{1}$, Cristina Morales ${ }^{2,4}$, Véronique Noé $^{1}$, Miguel A Peinado ${ }^{2,3}$ and Carlos J Ciudad*1
}

Address: ${ }^{1}$ Department of Biochemistry and Molecular Biology, School of Pharmacy, University of Barcelona, Barcelona, Spain, ${ }^{2}$ Institut d'Investigació Biomèdica de Bellvitge (IDIBELL), L'Hospitalet, Barcelona, Spain, 3'Institut de Medicina Predictiva i Personalitzada del Càncer (IMPPC), Badalona, Barcelona, Spain and ${ }^{4}$ Biotech Research and Innovation Centre (BRIC), University of, Copenhagen, Ole Maaløes Vej 5, DK2200 Copenhagen, Denmark

Email: Elisabet Selga - eliselga@ub.edu; Cristina Morales - cristina.morales@bric.dk; Véronique Noé - vnoe@ub.edu; Miguel A Peinado - map@imppc.org; Carlos J Ciudad* - cciudad@ub.edu

* Corresponding author

Published: II August 2008

BMC Medical Genomics 2008, I:35 doi:10.1 186/1755-8794-I-35
Received: 15 May 2008

Accepted: II August 2008

This article is available from: http://www.biomedcentral.com/I755-8794/I/35

(C) 2008 Selga et al; licensee BioMed Central Ltd.

This is an Open Access article distributed under the terms of the Creative Commons Attribution License (http://creativecommons.org/licenses/by/2.0), which permits unrestricted use, distribution, and reproduction in any medium, provided the original work is properly cited.

\begin{abstract}
Background: Methotrexate is one of the earliest cytotoxic drugs used in cancer therapy, and despite the isolation of multiple other folate antagonists, methotrexate maintains its significant role as a treatment for different types of cancer and other disorders. The usefulness of treatment with methotrexate is limited by the development of drug resistance, which may be acquired through different ways. To get insights into the mechanisms associated with drug resistance and sensitization we performed a functional analysis of genes deregulated in methotrexate resistant cells, either due to its co-amplification with the $\mathrm{dhfr}$ gene or as a result of a transcriptome screening using microarrays.

Methods: Gene expression levels were compared between triplicate samples from either HT29 sensitive cells and resistant to $10^{-5}$ M MTX by hybridization to the GeneChip ${ }^{\circledR}$ HG UI 33 PLUS 2.0 from Affymetrix. After normalization, a list of 3-fold differentially expressed genes with a $\mathrm{p}$-value $<0.05$ including multiple testing correction (Benjamini and Hochberg false discovery rate) was generated. RT-Real-time PCR was used to validate the expression levels of selected genes and copy-number was determined by qPCR. Functional validations were performed either by siRNAs or by transfection of an expression plasmid.

Results: Genes adjacent to the dhfr locus and included in the $5 \mathrm{q} / 4$ amplicon were overexpressed in HT29 MTX-resistant cells. Treatment with siRNAs against those genes caused a slight reduction in cell viability in both HT29 sensitive and resistant cells. On the other hand, microarray analysis of HT29 and HT29 MTX resistant cells unveiled overexpression of caveolin I, enolase 2 and PKC $\alpha$ genes in resistant cells without concomitant copy number gain. siRNAs against these three genes effectively reduced cell viability and caused a decreased MTX resistance capacity. Moreover, overexpression of E-cadherin, which was found underexpressed in MTX-resistant cells, also sensitized the cells toward the chemotherapeutic agent. Combined treatments targeting siRNA inhibition of caveolin I and overexpression of E-cadherin markedly reduced cell viability in both sensitive and MTX-resistant HT29 cells.
\end{abstract}

Conclusion: We provide functional evidences indicating that caveolin I and E-cadherin, deregulated in MTX resistant cells, may play a critical role in cell survival and may constitute potential targets for coadjuvant therapy. 


\section{Background}

Colorectal cancer is the third most common form of cancer and the second leading cause of cancer-related death in the Western world. Colon cancer causes 655,000 deaths worldwide per year [1]. Therapy is usually through surgery, followed in many cases by chemotherapy, which is used to slow tumor growth, to shrink tumor size and to reduce the likelihood of metastasis development.

Chemotherapy effectiveness in cancer cells is compromised by the achievement of drug resistance. Therefore, gaining insight into the mechanisms underlying drug resistance is basic to develop more effective therapeutic approaches. Morales et al. [2] hypothesized that the genetic features related with the progression pathway in colorectal cancer may condition its chemoresistance capability. In fact, it has been described that the tumor's ability to survive, grow and metastasize is conditioned by its genetic and phenotypic heterogeneity [3].

Methotrexate (MTX) is an antimetabolite and antifolate drug used in treatment of cancer and autoimmune diseases. MTX competitively and reversibly inhibits dihydrofolate reductase (DHFR), an enzyme that participates in folate metabolism, and essential for DNA synthesis and cell growth [4]. MTX is used for the treatment of lymphoblastic leukemia, lymphoma, osteosarcoma, breast cancer, and head and neck cancer [5]. Treatments combining MTX and other drugs are used in colorectal cancer [6-8]. However, MTX resistance can be easily acquired through different ways, although amplification of the target gene ( $d h f r$ ) has been shown to be the most important mechanism of resistance in cultured cells [9-11]. Indeed, amplification of 5q12-14 regions, where dhfr is located, has been described in MTX-resistant HT29 cells [2].

In the present study, we wanted to identify genes implicated in MTX resistance in HT29 colon cancer cells and to explore their relative contribution to this phenotype. We analyzed the differential gene expression between MTXresistant and MTX-sensitive HT29 cells using oligonucleotide microarrays containing the full human genome. Changes in the DNA content between both cell lines were also determined. We showed a role for specific differentially expressed genes in MTX resistance. Using siRNAs against caveolin 1, enolase 2 and PKC $\alpha$ or plasmid overexpression for E-cadherin, a clear chemosensitization toward MTX was observed.

\section{Methods \\ Cell Culture}

Human colon adenocarcinoma cell line HT29 was routinely grown in Ham's F12 medium supplemented with $7 \%$ fetal bovine serum (FBS, both from Gibco) at $37^{\circ} \mathrm{C}$ in a $5 \% \mathrm{CO}_{2}$ humidified atmosphere. Cells resistant to $10^{-5}$
M MTX, which corresponds to a 1000-fold increase in resistance with respect to the sensitive cells, were previously obtained in the laboratory [12] upon incubation with stepwise concentrations of MTX (Lederle) and were rutinely grown in selective DHFR medium (-GHT medium, GIBCO) lacking glycine, hypoxanthine and thymidine, the final products of DHFR activity. This medium was supplemented with $7 \%$ dialyzed fetal bovine serum (GIBCO).

\section{Microarrays}

Gene expression was analyzed by hybridization to the GeneChip ${ }^{\circledast}$ Human Genome U133 PLUS 2.0 from Affymetrix, containing over 47,000 transcripts and variants. Total RNA for oligo arrays was prepared from triplicate samples of both HT29 sensitive and resistant cells using the RNAeasy Mini kit (Qiagen) following the recommendations of the manufacturer. Labeling, hybridization and detection were carried out following the manufacturer's specifications. The data discussed in this publication have been deposited in NCBIs Gene Expression Omnibus [13] and are accessible through GEO Series accession number GSE11440.

\section{Microarray data analysis}

Quantification was carried out with GeneSpring GX software v 7.3.1 (Silicon Genetics), which allows multi-filter comparisons using data from different experiments to perform the normalization, generation of restriction lists and functional classifications of the differentially expressed genes. Normalization was applied in two steps: i) "per Chip normalization" by which each measurement was divided by the 50th percentile of all measurements in its array; and ii) "per Gene normalization" by which all the samples were normalized against the median of the control samples (HT29 sensitive cells). The expression of each gene was reported as the ratio of the value obtained after each condition relative to the control condition after normalization of the data. Then, data were filtered using the control strength, a control value calculated using the Cross-Gene Error Model on replicates [14] and based on average base/proportional value. Measurements with higher control strength are relatively more precise than measurements with lower control strength. Genes that did not reach this value were discarded. Additional filtering was performed to determine differentially expressed genes. A restriction t-test p-value of less than 0.05 including multiple testing correction (Benjamini and Hochberg false discovery rate) was applied. The output of this analysis was then filtered by fold expression, to specifically select those genes that had a differential expression of at least 3-fold. The 375 transcripts included in this list can be viewed in Additional file 1. 


\section{RT-Real-Time PCR}

mRNA levels of the different selected genes were determined by RT-Real-time PCR. Total RNA was extracted from cells $\left(4 \times 10^{6}\right)$ using Ultraspec ${ }^{\mathrm{Tm}}$ RNA reagent (Biotecx) following the recommendations of the manufacturer. Complementary DNA was synthesized in a total volume of $20 \mu \mathrm{l}$ from RNA samples by mixing $500 \mathrm{ng}$ of total RNA, $125 \mathrm{ng}$ of random hexamers (Roche), in the presence of $75 \mathrm{mM} \mathrm{KCl}, 3 \mathrm{mM} \mathrm{MgCl} 2,10 \mathrm{mM}$ dithiothreitol, 20 units of RNasin (Promega), $0.5 \mathrm{mM}$ dNTPs (AppliChem), 200 units of M-MLV reverse transcriptase (Invitrogen) and $50 \mathrm{mM}$ Tris- $\mathrm{HCl}$ buffer, $\mathrm{pH}$ 8.3. The reaction mixture was incubated at $37^{\circ} \mathrm{C}$ for $60 \mathrm{~min}$ and the cDNA product was used for subsequent Real-time PCR amplification using SYBR Green. A standard $20 \mu \mathrm{l}$ reaction contained $25 \mathrm{ng}$ of the cDNA mixture, $0.5 \mu \mathrm{M}$ of the forward and reverse primers and the SYBR Green Master Mix. Primers used are listed in the Additional file 2.

\section{Determination of gene copy number}

Genomic DNA from either HT29 sensitive or resistant cells was obtained with the Wizard ${ }^{\mathrm{TM}}$ Genomic DNA Purification Kit (Promega) following the manufacturer's recommendations. Five nanograms of DNA were used for Real-Time PCR amplification in a $20 \mu \mathrm{l}$ reaction containing $0.5 \mu \mathrm{M}$ of the forward and reverse primers and the SYBR Green Master Mix in an ABI Prism 7000 Sequence Detection System (Applied Biosystems). A list of the primers used is provided as Additional file 3.

\section{Functional validations}

A) transfection of siRNAs against selected genes

HT29 cells $(30,000)$ were plated in $1 \mathrm{ml}$ of -GHT medium and transfection was performed eighteen hours later. For each well, $4 \mu \mathrm{l}$ of Lipofectamine ${ }^{\mathrm{TM}} 2000$ (Invitrogen) in $100 \mu \mathrm{l}$ of serum free-GHT medium were mixed in Eppendorf tubes with $100 \mathrm{nM}$ of siRNA in $100 \mu \mathrm{l}$ of serum free -GHT medium. The mixture was incubated at room temperature for $20 \mathrm{~min}$ before addition to the cells. MTX ( $5 \times$ $10^{-8} \mathrm{M}$ ) was added 48 hours after siRNA treatment and MTT assays were performed [15] after 5 days from the beginning of the treatment. Treatment of HT29 resistant cells was performed following the same protocol using 2 $\mu \mathrm{l}$ of Lipofectamine $\mathrm{T}^{\mathrm{TM}} 2000$ and $10^{-5} \mathrm{M}$ MTX. When screening for mRNA levels of the different genes after siRNA treatment, 30,000 cells, either sensitive or resistant, were incubated with increasing amounts of siRNA (1-100 nM) maintaining a 3:1 ratio ( $\mu$ l of Lipofectamine : $\mu \mathrm{g}$ siRNA) and following the procedure previously described. Cells were harvested 48 hours after siRNA treatment for RNA extraction and RT-Real-time PCR. In the combination experiments with siRNAs, $100 \mathrm{nM}$ of each siRNA were diluted in the same eppendorf containing $100 \mu \mathrm{l}$ of serum free -GHT medium and combined with Lipofectamine ${ }^{\mathrm{TM}}$ 2000 as described above. MTX was added as in the single
siRNA experiments, mRNA levels were determined and MTT was performed as previously described. In all cases, a non-related siRNA was used as negative control. The treatment was performed as described above and cell viability and mRNA levels for each gene were quantified in parallel. The siRNAs were designed using the software iRNAi. Then, BLAST resources in NCBI were used to assess the degree of specificity of the sequence recognition for these siRNAs. We only selected the siRNAs that reported the target gene as the only mRNA hit. The sequences for the sense strand of all siRNAs used are available in the supplementary material provided (see Additional file 4).

B) transfection of an expression plasmid encoding for E-cadherin HT29 cells were seeded into 6-well plates at a density of 3 $\times 10^{4}$ cells/well in $1 \mathrm{ml}$ of HAM F12 selective medium. Eighteen hours later, transfections with the expression plasmid for E-cadherin (pBATEM2-CDH) were performed in the presence or in the absence of MTX. The overexpression of E-cadherin was monitored by determining its mRNA levels after $48 \mathrm{~h}$ upon transfection. For each well, Lipofectamine ${ }^{\mathrm{TM}} 2000$ was diluted in $100 \mu \mathrm{l}$ of serum free -GHT medium and was combined with different amounts of the plasmid (500 ng-5 $\mu \mathrm{g}$ ) in $100 \mu \mathrm{l}$ of serum free -GHT medium, always maintaining a $2: 1$ ratio ( $\mu$ l of Lipofectamine : $\mu \mathrm{g}$ of plasmid). After $20 \mathrm{~min}$ at room temperature, the mixture was added to the cells. When combining pBATEM2-CDH transfection and MTX treatment, $5 \times 10^{-8} \mathrm{M}$ MTX was added $48 \mathrm{~h}$ after transfection. Cell viability was measured by the MTT assay after 5 days from the beginning of the treatment. Treatment of HT29 resistant cells was performed following the same steps but using $10^{-5} \mathrm{M}$ MTX.

\section{C) co-transfection of siCAVI and pBATEM2-CDH}

When transfection of siCAV1 and pBATEM2-CDH was performed simultaneously, $100 \mathrm{nM}$ of siRNA and $1 \mu \mathrm{g}$ of plasmid were diluted together in Eppendorf tubes with $100 \mu \mathrm{l}$ of serum free -GHT medium and mixed with lipofectamine $^{\mathrm{TM}} 2000$ in $100 \mu \mathrm{l}$ of serum free-GHT medium ( 6 $\mu \mathrm{l}$ for the sensitive cells and $3 \mu \mathrm{l}$ for the MTX-resistant cells). The mixture was incubated at room temperature for $20 \mathrm{~min}$ before addition to the cells $\left(3 \times 10^{4}\right.$ cells/well in 1 ml of HAM F12 selective medium, pre-seeded eighteen hours earlier). The mRNA levels after transfection were determined for both genes as previously described and MTT assay was used to determine cell viability.

\section{Results \\ Identification of genes deregulated in association with MTX resistance}

The expression profile of the 47,000 transcripts and variants included in the HG U133 PLUS 2.0 microarray from Affymetrix was compared between HT29 sensitive cells and resistant to $10^{-5} \mathrm{M}$ MTX. GeneSpring GX software 
v7.3.1 was used to analyze the results. A list of 3-fold differentially expressed genes was generated as described in Methods (Additional file 1). The expression values for genes in this list can be viewed in their corresponding chromosomal position (Figure 1). This overlapping view evidenced a highly overexpressed region in chromosome 5 that covers $d h f r$ and the surrounding loci. The set of upregulated genes in this location included $d h f r$, zfyve16, msh3, rasgrf2, ssbp2, xrcc4, hapln1 and edil3 (Figure 2), which were selected for further studies. Additional genes that were clearly overexpressed or underexpressed and located in other human chromosomes were also selected according to their function and after literature mining of genes related to drug resistance. The expression levels of most of the selected genes were validated by RT-Real-time PCR (Table 1). The correlation between microarray and qPCR was calculated using the log-transformed values of the fold change obtained for the selected genes, obtaining an r-value of 0.95 . To test if changes in the DNA content were responsible for the expression levels of the selected genes in the resistant cells, we determined the copy number for all of them using Real-Time PCR. The results, presented in table 1, showed amplification of all the genes in chromosome 5 flanking $d h f r$, as well as of mtus1, located in chromosome 8. E-cadherin was the only gene clearly lost among the selected genes.

\section{Effect on MTX sensitivity of siRNAs against genes flanking dhfr}

To investigate if the genes that were both overexpressed and co-amplified with $d h f r$ contributed to MTX resistance, their mRNA levels were brought down by means of siRNAs. Effective reduction $(\approx 70 \%)$ of the respective mRNAs was obtained upon transfection of $100 \mathrm{nM}$ of each single siRNA, both in sensitive and resistant cells. These treatments, though, caused a small reduction in the viability of both cell lines, and addition of MTX to the siRNAs did not sensitize the cells toward the chemotherapeutic agent (data not shown). On the contrary, a siRNA against $d h f r$ mRNA ( $30 \%$ in HT29 sensitive cells, which was increased up to $90 \%$ with the addition of MTX (Figure 3B). mRNA levels after siDHFR treatment were reduced by $70 \%$ in this cell line (Figure 3A).

Table I: mRNA levels and copy number determination of differentially expressed genes in HT29 MTX-resistant cells.

\begin{tabular}{|c|c|c|c|c|c|c|}
\hline \multirow[t]{2}{*}{ GenBank } & \multirow[t]{2}{*}{ Gene Name } & \multirow[t]{2}{*}{ Chromosome } & \multirow{2}{*}{$\begin{array}{l}\text { Copy Number } \\
\text { (Q-PCR) }\end{array}$} & \multicolumn{2}{|c|}{ Expression } & \multirow[t]{2}{*}{ Gene Function } \\
\hline & & & & Microarrays & Validation (RT-PCR) & \\
\hline NM 002961 & SI00A4 & I & $0.85 \pm 0.1$ & $3.7\left(p=5.5 \mathrm{e}^{-6}\right)$ & $5.68 \pm 0.4$ & Angiogenesis \\
\hline BU078629 & ZFYVEI6 & 5 & $16.81 \pm 2.1$ & $6.1\left(p=7.7 e^{-6}\right)$ & $6.7 \pm<0.1$ & Zinc ion binding \\
\hline All 44299 & DHFR & 5 & $16.09 \pm 1.4$ & $7.1\left(p=1.2 e^{-7}\right)$ & $11.05 \pm 0.5$ & Nucleotide metabolism \\
\hline NM 002439 & $\mathrm{MSH} 3$ & 5 & $4.97 \pm 0.5$ & $3.9\left(p=5.5 e^{-6}\right)$ & $4.23 \pm 0.4$ & Missmatch repair \\
\hline $\mathrm{A} 1912976$ & RASGRF2 & 5 & $17.76 \pm 0.4$ & $4.6\left(p=8.9 e^{-5}\right)$ & $6.10 \pm 0.5$ & MAPK signaling \\
\hline$\overline{\mathrm{AF} 912976}$ & SSBP2 & 5 & $10.27 \pm 0.7$ & $2.4\left(p=3.4 \mathrm{e}^{-3}\right)$ & $2.96 \pm 0.2$ & ss DNA binding \\
\hline NM 022406 & $\mathrm{XRCC} 4$ & 5 & $17.31 \pm 1.1$ & $7.1\left(p=4.7 e^{-6}\right)$ & $8.90 \pm 2.3$ & ds break repair \\
\hline$\underline{\mathrm{U} 43328}$ & HAPLNI & 5 & $11.55 \pm<0.1$ & $147\left(p=2.9 e^{-10}\right)$ & $1111.9 \pm 80.7$ & Cell adhesion \\
\hline AA0537II & EDIL3 & 5 & $14.3 \pm 0.7$ & $157\left(p=9.1 e^{-8}\right)$ & N/D & Cell adhesion \\
\hline U17496 & PSMB8 & 6 & $0.91 \pm<0.1$ & $0.1(p=0.01)$ & N/D & Proteasome subunit \\
\hline NM 004666 & VNNI & 6 & $0.84 \pm<0.1$ & $0.04(p=0.01)$ & N/D & Nitrogen metabolism \\
\hline$\overline{A U 147399}$ & CAVI & 7 & $1.14 \pm<0.1$ & $10.9\left(p=1.5 e^{-4}\right)$ & $15.00 \pm 0.8$ & Integ. plasma membr. \\
\hline BE552421 & MTUSI & 8 & $3.52 \pm 0.1$ & $3.4\left(\mathrm{p}=1.8 \mathrm{e}^{-6}\right)$ & N/D & Mitoc. tumor suppressor \\
\hline U05598 & AKRICI & 10 & $0.94 \pm<0.1$ & $4,6\left(p=3.9 \mathrm{e}^{-6}\right)$ & $6.72 \pm 0.7$ & Xenobiotics metabolism \\
\hline NM 001975 & ENO2 & 12 & $0.92 \pm<0.1$ & $6.0\left(p=4.6 \mathrm{e}^{-6}\right)$ & $3.90 \pm 0.1$ & Glycolisis \\
\hline AK000345 & DHRS2 & 14 & $0.97 \pm<0.1$ & $0.12(p=0.01)$ & N/D & Oxidoreductase \\
\hline L08599 & $\mathrm{CDHI}$ & 16 & $0.33 \pm<0.1$ & $0.19(p=0.01)$ & $0.15 \pm<0.1$ & Cell adhesion \\
\hline $\mathrm{Al} 471375$ & PRKCA & 17 & $1.05 \pm<0.1$ & $4.2\left(p=1.7 e^{-5}\right)$ & $2.55 \pm 0.2$ & Regulation cell cycle \\
\hline$\overline{\mathrm{BQ} 003811}$ & SLCI9AI & 21 & $0.84 \pm<0.1$ & $0.1(p=0.01)$ & N/D & Cell adhesion \\
\hline NM 001569 & IRAKI & $x$ & $1.25 \pm<0.1$ & $0.26\left(p=7.3 \mathrm{e}^{-3}\right)$ & N/D & ILI receptor Kinase \\
\hline NM 004135 & IDH3G & $x$ & $0.85 \pm<0.1$ & $0.28\left(p=7.3 e^{-8}\right)$ & N/D & TCA cycle \\
\hline NM 001183 & ATP6API & $x$ & $0.68 \pm<0.1$ & $0.3(p=0.01)$ & N/D & ATP biosynthesis \\
\hline
\end{tabular}

Twenty-two genes belonging to the 3-fold differentially expressed list were selected according to their possible relation with drug resistance and/or chromosomal localization. It is shown the GenBank accession number of all genes next to their common name, and their chromosome number. Real-Time PCR was used to determine their copy number, and the expression levels for all them are presented both as the values found in the microarrays (in fold changes relative to the control; t-test $p$-values included) and as validated mRNA levels (using RT-Real-Time PCR). All experimental results are expressed as fold changes referred to the sensitive cells and values are the mean of triplicate experiments \pm SE. The last column indicates the functional categories of the genes. N/D, nondetermined value. 


\section{S100A4 \\ $1 \mathrm{n}$

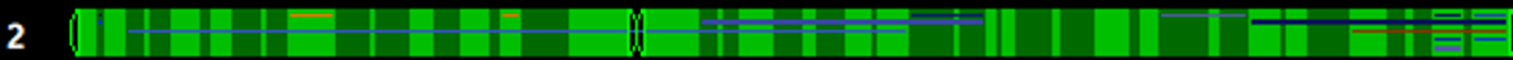 \\ 3 ब}

6

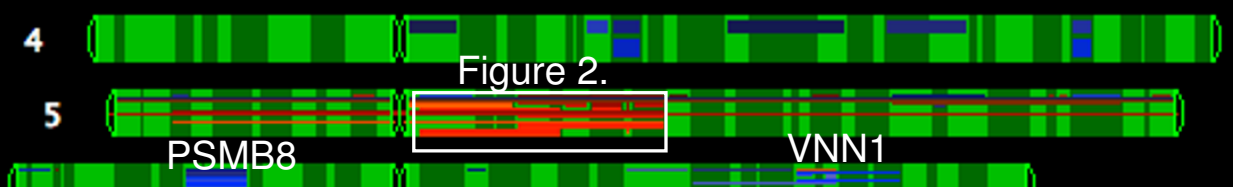

7

$$
\text { CAV1 }
$$
MTUS1

8

르

9 ( 1 늘

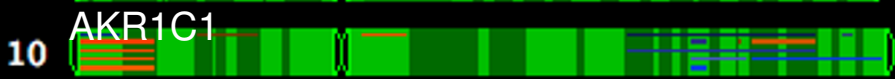

11

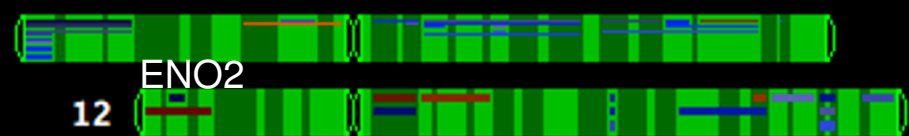

13

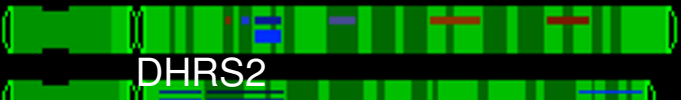

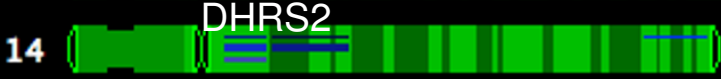

150 - 110

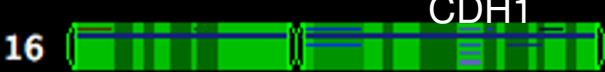

$17 \|=-P K C \alpha$

$18 \llbracket(10) \square$

19 (1)

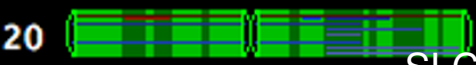
SLC19A1

210 年国

22 in

$\mathbf{x}$

\section{Figure I}

Chromosomal view of the differentially expressed genes in HT29 MTX-resistant cells. The expression values of genes included in the 3-fold differentially expressed list were viewed in their respective chromosomal location. The names for all the genes studied are depicted on top of their chromosome position. Red is used to color the overexpressed genes and blue is used to highlight the underexpressed genes. 


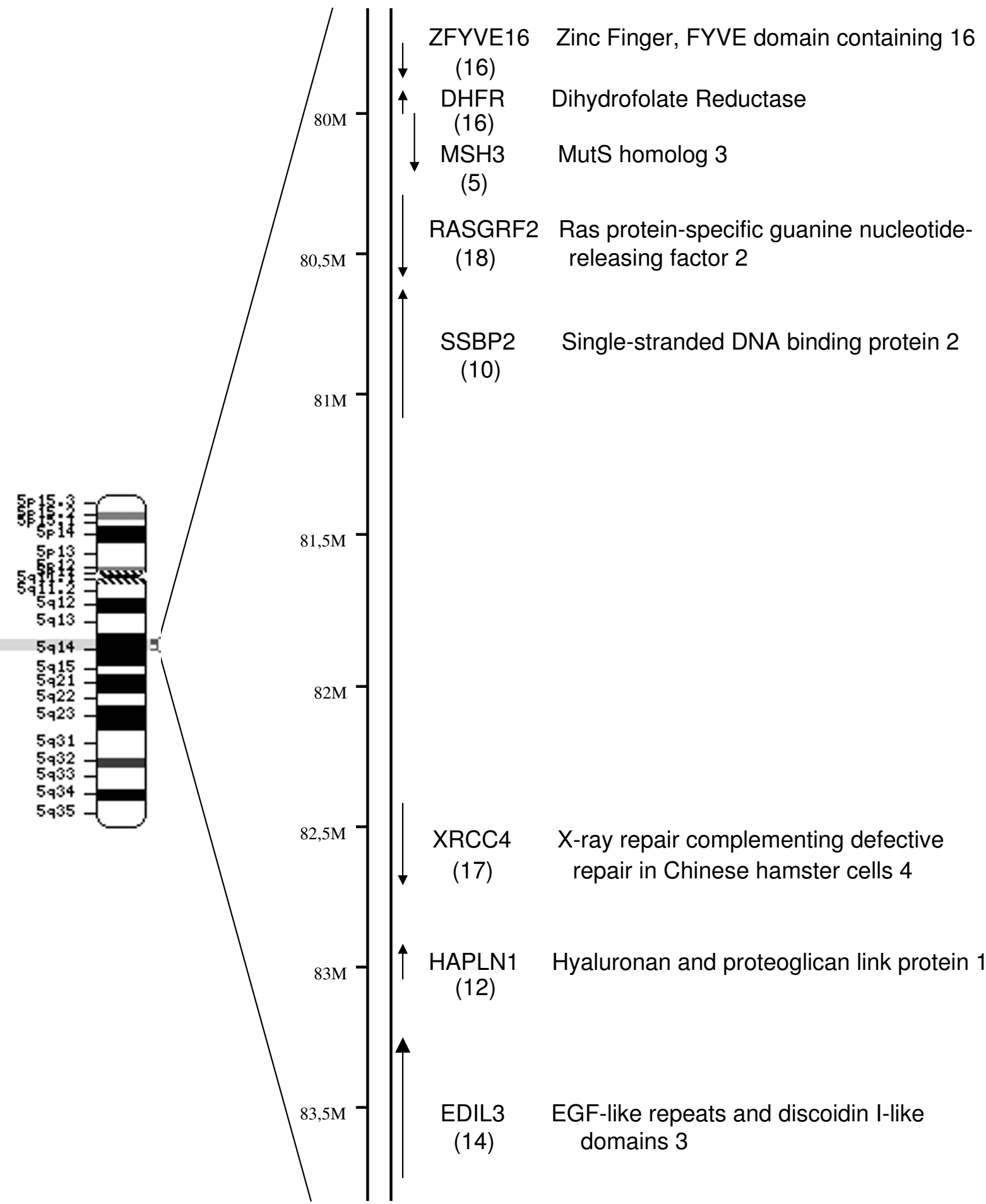

Figure 2

Localization of dhfr and other genes in chromosome 5 that are overexpressed in HT29 MTX-resistant cells. It is presented a magnification of the region in chromosome 5 where dhfr is located $(5 q / 4)$. The left part is an ideogram of chromosome 5; the right part shows the relative position of all genes studied that are located in this chromosome and that were amplified. The arrows indicate their transcription orientation and the values in parentheses under the names correspond to their respective copy-number validated by Real-time PCR. 


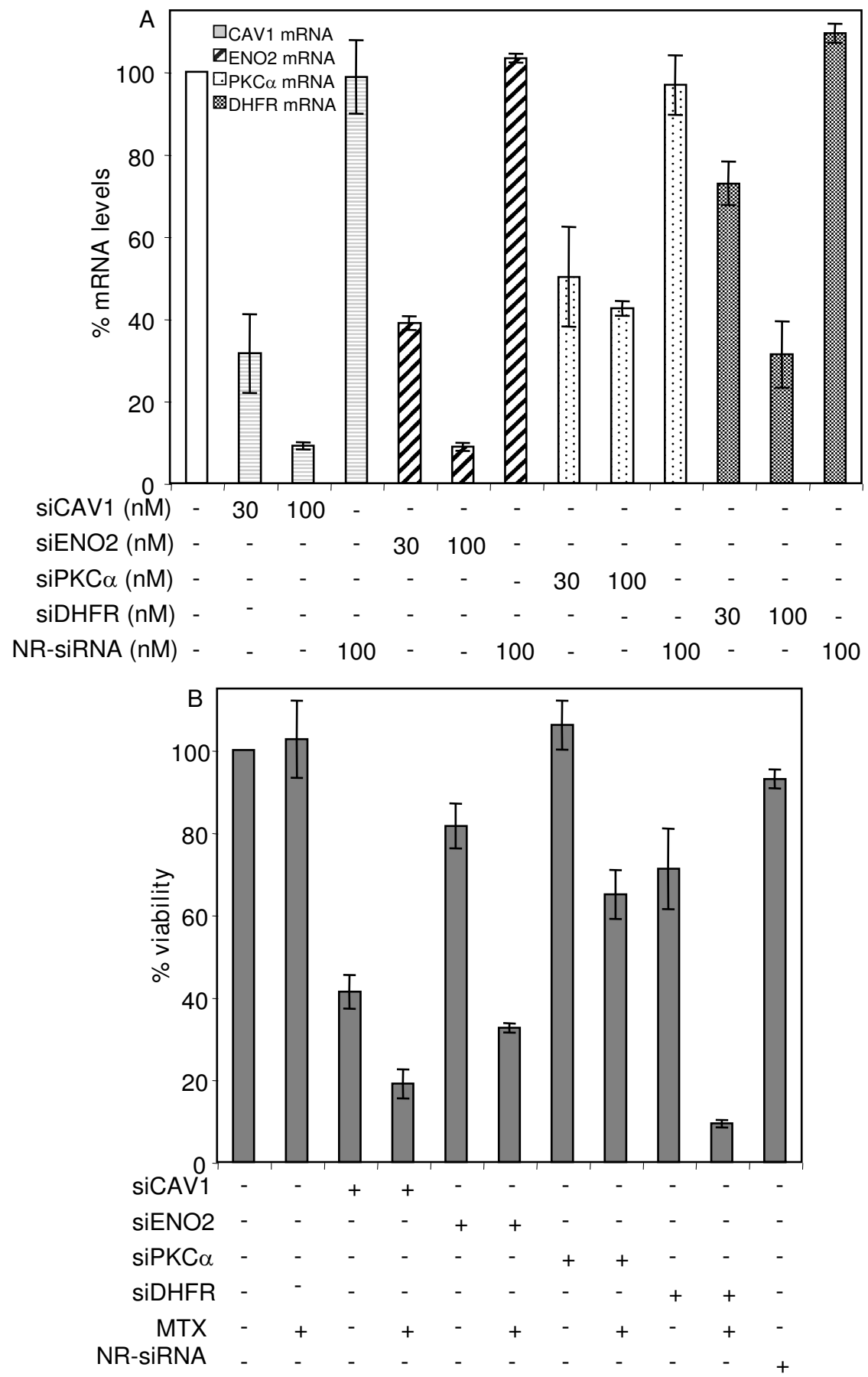

Figure 3

Determination of mRNA levels and cytotoxicity upon siRNA treatment of HT29 sensitive cells. (A) The mRNA levels of CAVI, ENO2, PKC $\alpha$ and DHFR were determined by RT-Real-time PCR $48 \mathrm{~h}$ after treatment of HT29 cells with the indicated concentrations of siCAVI, siENO2, siPKC $\alpha$, siDHFR and a non-related siRNA. Symbols used for each mRNA are presented as an insert within the figure. (B) Cells were treated with $100 \mathrm{nM}$ of each siRNA as previously described and $5 \times 10$ $8 \mathrm{M}$ MTX was added after $48 \mathrm{~h}$. Cell viability was determined after 5 days from the beginning of the treatment. All results are expressed as percentages referred to untreated cells. Values are the mean of three independent experiments \pm SE. A nonrelated (NR) siRNA was used as negative control. 


\section{Effect on MTX sensitivity of siRNAs against CAVI, ENO2,} PKC $\alpha$ and DHFR

As the knocking down of genes co-amplified with $\mathrm{dhfr}$ showed only a slight contribution to MTX sensitivity, we focused in three genes that were clearly overexpressed in the resistant cells and located in different chromosomes, namely caveolin 1(CAV1), enolase 2 (ENO2) and PKCa. We quantified the mRNA levels of these three genes after treatment with different concentrations of the corresponding siRNA using RT-Real-time PCR. The three siRNAs were effective in reducing the mRNA levels of their targets, both in sensitive (Figure 3A) and in MTX-resistant (Figure 4) HT29 cells. One hundred nanomolar was the most effective concentration for all of them, and was used in subsequent experiments. The mRNA levels upon treatment with the siRNA against DHFR are also presented in these series (Figure 3A \&4). The mRNA levels of the four genes after treatment with their respective siRNAs in the resistant cells were reduced down almost to the expression levels found for these genes in HT29 sensitive cells (compare Y-axes between Figure 3A \&4). A non-related siRNA was used as negative control, and did not produce any significant reduction on the mRNA levels of any of the four genes, either in sensitive or in resistant HT29 cells.

Viability of HT29 sensitive cells (Figure 3B) was moderately reduced upon treatment with $100 \mathrm{nM}$ siENO2 or siDHFR and treatment with siCAV1 caused a marked reduction of cell viability on its own. No effect on cell viability was observed upon treatment with siPKC $\alpha$. In all cases, treatment with $100 \mathrm{nM}$ of each single siRNA increased the sensitivity of HT29 cells toward MTX with respect to the control: $80 \%$ when using siCAV1; $70 \%$ with siENO2; $40 \%$ with siPKC $\alpha$ and $90 \%$ when siDHFR was used. However, when the same treatments were performed in MTX-resistant cells (data not shown), cell viability was reduced only by $15 \%$ when using either siCAV1, siENO2 or siPKC $\alpha$, and by $25 \%$ when siDHFR was used. None of these effects were improved by the combination of siRNAs with MTX. Transfection with $100 \mathrm{nM}$ of a nonrelated siRNA did not cause any significant reduction on cell viability, either in sensitive or in resistant HT29 cells.

\section{Effect of the combination of siRNAs against CAVI, ENO2, PKC $\alpha$ and DHFR on MTX sensitivity}

As we had observed a chemosensitization toward MTX in sensitive cells when using individual siRNAs, we performed experiments including the siRNAs against CAV1, ENO2 and PKC $\alpha$ (triple combination) or in combination with siDHFR (quadruple combination) to test if these combinations also increased the sensitivity toward MTX. Treatments combining the three siRNAs (siCAV1, siENO2 and siPKC $\alpha$ ) at $100 \mathrm{nM}$ each reduced cell viability by $30 \%$ and effectively increased MTX sensitivity by $60 \%$ with respect to the control in HT29 sensitive cells (Figure 5A).
Addition of $100 \mathrm{nM}$ siDHFR to the previous combination caused a reduction on cell viability of the same degree as the triple combination but increased MTX sensitivity to about 75\%. In the case of MTX-resistant HT29 cells, treatments were performed with the same combinations (Figure $5 \mathrm{~B}$ ). The triple combination reduced cell viability by $15 \%$ on its own. However, MTX sensitivity was not improved. The quadruple combination did not affect cell viability on its own but caused a reduction of $20 \%$ on cell viability when combined with MTX. It was confirmed that the mRNA levels of the four genes were decreased after the siRNA combination treatments in both cell lines (Table 2 ). Treatments with a non-related siRNA at $400 \mathrm{nM}$ were performed in order to assess the citotoxicity of triple and quadruple combinations and to verify the mRNA levels of all four genes. No effect was observed in any case in either sensitive or resistant cells.

\section{Effect of overexpressing E-cadherin on its mRNA levels, cell viability and $M T X$ sensitivity}

Since E-cadherin was lost and underexpressed in the resistant cells, it was transiently expressed in HT29 sensitive and resistant cells by means of an expression vector (pBATEM2-CDH). Cells were harvested after 48 hours of treatment. RT-Real-Time PCR was used to quantify E-cadherin mRNA levels in both cell lines (Figure 6A \&6B). Transfection of more than $1 \mu \mathrm{g}$ of the expression vector caused a marked reduction on cell viability in both cell lines. Therefore, $1 \mu \mathrm{g}$ of plasmid was used in all subsequent experiments. Overexpression of E-cadherin was performed in HT29 sensitive cells in the absence or in the presence of $5 \times 10^{-8} \mathrm{M}$ MTX. This treatment increased by $50 \%$ the effect of methotrexate (Figure $6 \mathrm{C}$ ), thus providing evidence that loss of E-cadherin can confer increased resistance of HT29 cells toward MTX. The same approach was used with HT29 resistant cells, in combination or not with $10^{-5} \mathrm{M}$ MTX. Overexpression of E-cadherin reduced by $10 \%$ cell viability of the resistant cells and only a small improvement was observed when combining E-cadherin overexpression with MTX treatment (Figure 6D).

\section{Effect of co-transfection of siCAVI and pBATEM2-CDH on MTX sensitivity}

E-cadherin has been shown to be an important permissive element in defining the functions of CAV1 [16]. Thus, we performed co-transfection experiments to reduce the mRNA levels of CAV1 and to overexpress E-cadherin simultaneously. mRNA levels after co-transfection were determined in both cell lines (Table 3 ). As observed in figure $7 \mathrm{~A}$, altering the mRNA levels for the two genes reduced the viability of HT29 sensitive cells by almost $40 \%$. Moreover, addition of MTX to the previous combination further reduced cell viability by $90 \%$. Importantly, when performing these co-transfection experiments in HT29 resistant cells, cell viability was reduced by $80 \%$, 
A

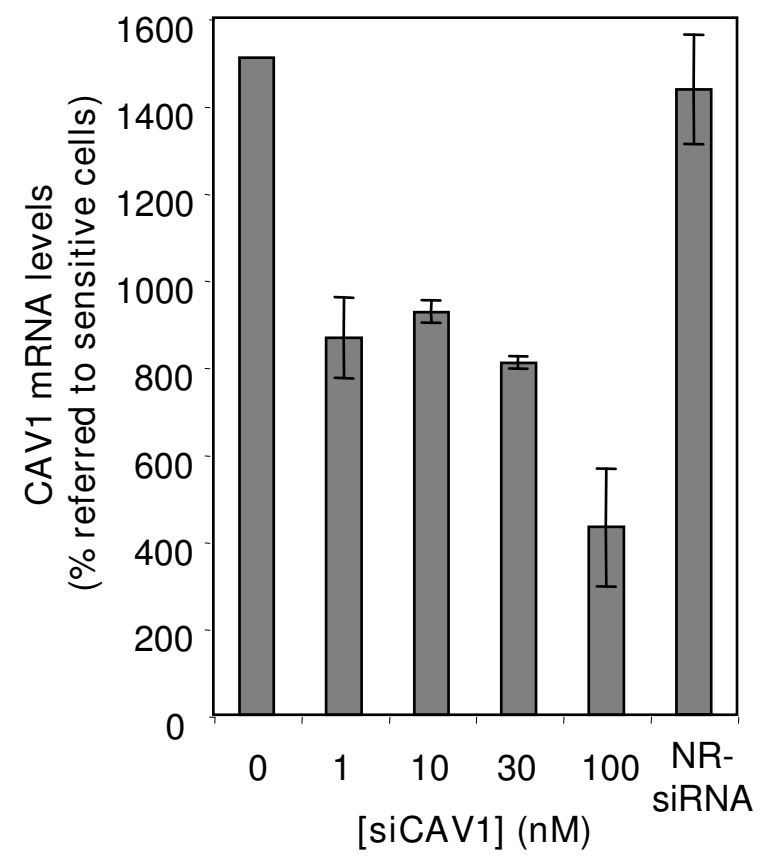

C

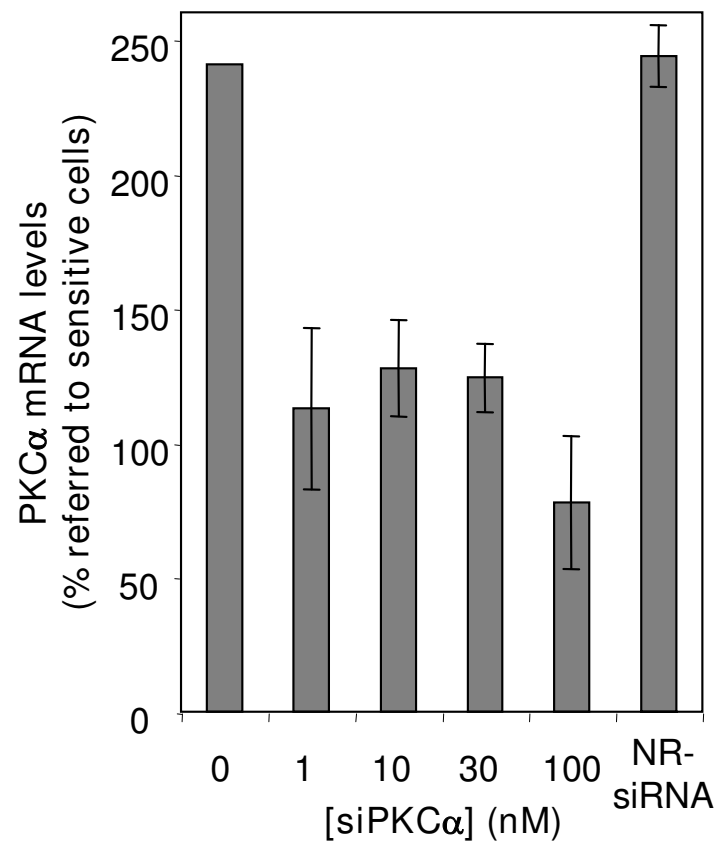

B
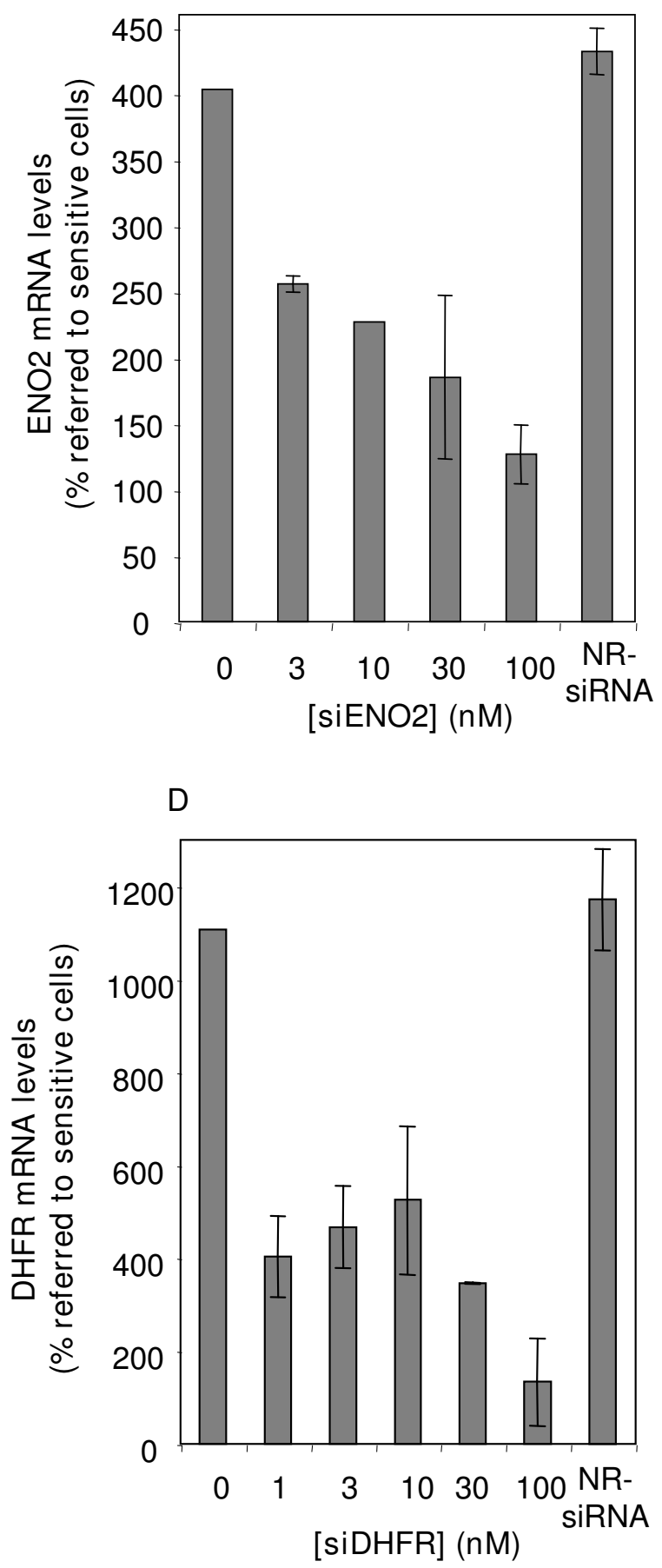

\section{Figure 4}

mRNA levels of CAVI, ENO2, PKC $\alpha$ and DHFR upon siRNA treatment of MTX-resistant cells. Treatments with increasing amounts of each siRNA were performed in MTX-resistant HT29 cells. Forty-eight hours later, mRNA levels for each gene were determined and expressed as percentages of the untreated control (A, CAVI; B, ENO2; C, PKC $\alpha$ and D, DHFR). A non-related (NR) siRNA was used as negative control. Results are depicted taking into account the relative gene expression in the resistant cells (\% of the sensitive cells). Values are the mean of three independent experiments \pm SE. 
A

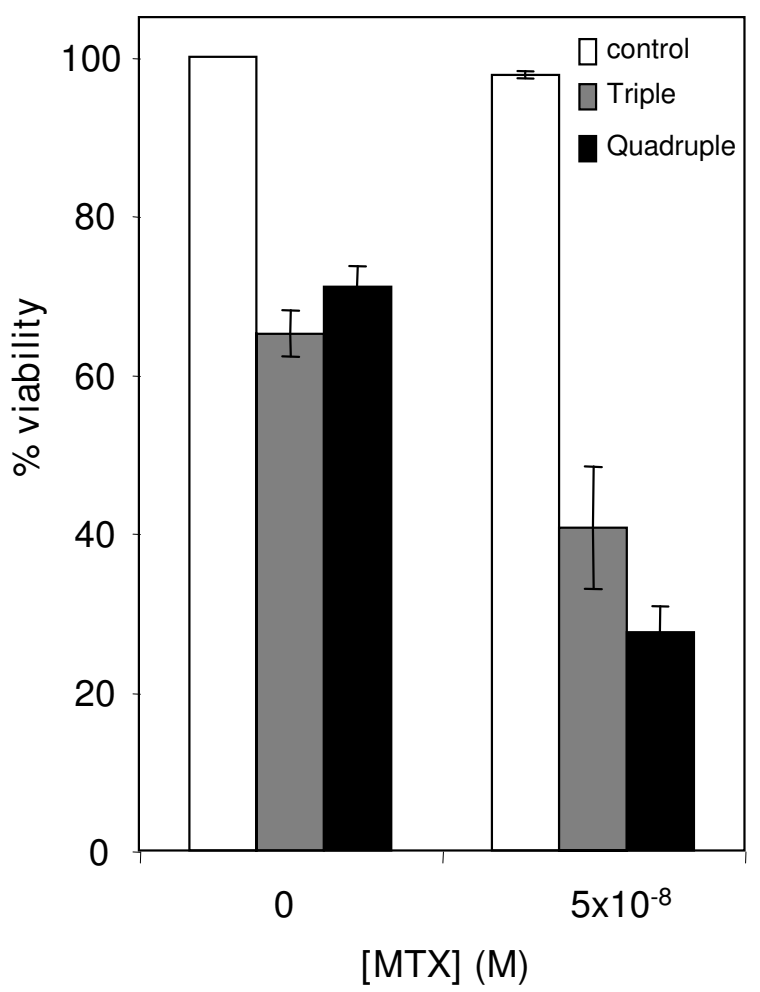

B

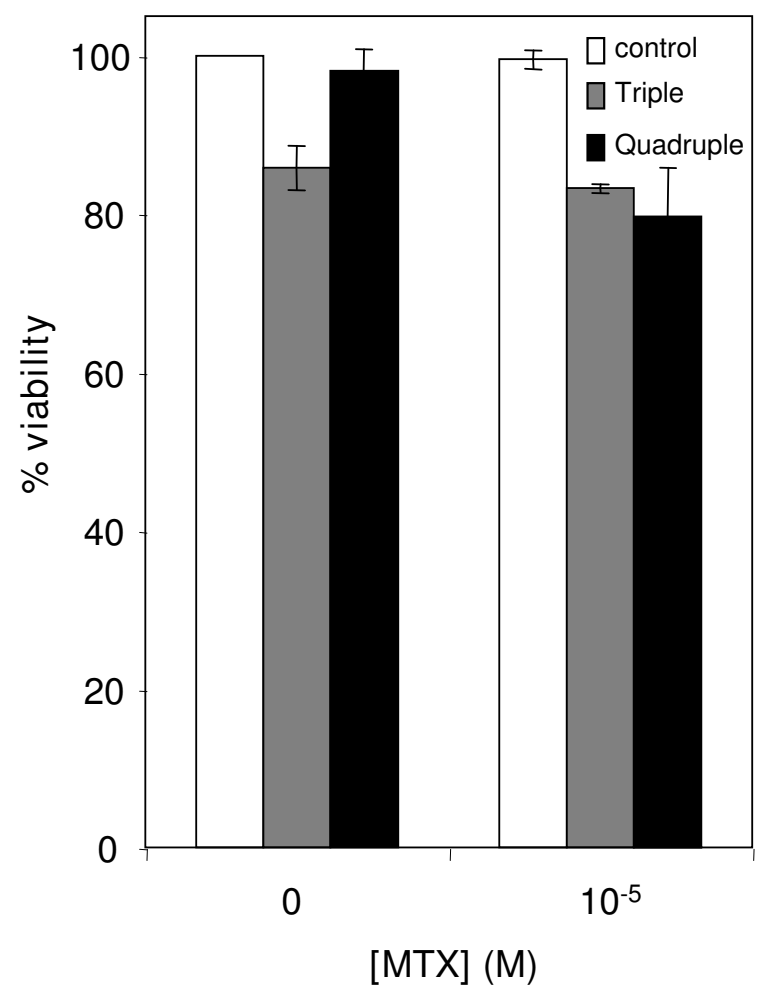

\section{Figure 5}

Effects of combining siRNAs against CAVI, ENO2, PKC $\alpha$ and DHFR on MTX sensitivity. Treatments with combinations of siRNAs at $100 \mathrm{nM}$ each were performed both in sensitive (A) and in resistant cells (B). MTX was added after $48 \mathrm{~h}$ and cell viability was determined by the MTT assay after 5 days from the beginning of the treatment. The triple combination includes the siRNAs against CAVI, ENO2 and PKC $\alpha$; the quadruple combination includes the three previous siRNAs plus siDHFR. Results are presented as percentages referred to the untreated cells. Values are the mean of three independent experiments $\pm \mathrm{SE}$.

although in this instance MTX did not improve the effect (Figure 7B).

\section{Discussion}

In the present study, genes differentially expressed in HT29 colon cancer cells resistant to MTX were identified and their relative contribution to this phenotype evaluated. We observed a cluster of genes flanking the dhfr locus in chromosome 5 that were overexpressed in MTX-resistant HT29 cells. Two of the genes included in this cluster, MSH3 and XRCC4, are known to be involved in DNA repair [17-19]; other two, RASGRF2 and SSBP2, have been related to signaling pathways [20-22]; and EDIL3 has been suggested to prevent apoptosis and to promote cell proliferation $[23,24]$. Despite the confirmation of the coamplification of all these genes with $d h f r$ in the resistant cells, we did not observe a clear sensitization toward MTX when reducing their respective mRNA levels by means of
iRNA technology. Our observations indicate that the increase in copy-number and the resulting upregulation of the studied genes in $5 q 14$ may be a consequence of $d h f r$ amplification more than an adaptation of the cells to MTX resistance. Indeed, many mammalian species (mouse, rat, bull, cock, dog and chimpanzee) show this set of genes in the same order around $d h f r$ as in human chromosome 5 (using the MapViewer at NCBI), indicating a conserved pattern of gene organization. In keeping with this, its overexpression in the resistant cells could have been useful to improve some cellular processes that might facilitate survival. However, as shown in this work, the increase in copy number of this set of genes does not favor MTX resistance. Thus, we decided to search for other differentially expressed genes (CAV1, E-cadherin, ENO2 and $\mathrm{PKC} \alpha$ ) that had been previously related with resistance or with colon cancer and to evaluate their relative contribution in our cell system. 
Table 2: mRNA levels upon treatment with combination of siRNAs against CAVI, ENO2, PKC $\alpha$ and DHFR.

\begin{tabular}{|c|c|c|c|c|}
\hline$A$ & & & & \\
\hline Treatment & CAVI & ENO2 & $\mathrm{PKC} \alpha$ & DHFR \\
\hline $\operatorname{siCAVI}+\operatorname{siENO} 2+\operatorname{siPKC} \alpha$ & $50.1 \pm 4.3$ & $50.5 \pm 4.4$ & $66.2 \pm 2.6$ & $82.9 \pm 2.3$ \\
\hline $\operatorname{siCAVI}+\operatorname{siENO} 2+\operatorname{siPKC} \alpha+\operatorname{siDHFR}$ & $37.7 \pm 3.7$ & $59.1 \pm 0.8$ & $47.6 \pm 4.7$ & $47.3 \pm 1.2$ \\
\hline $400 \mathrm{nM} N R-s i R N A$ & $96.8 \pm 10.4$ & $98.4 \pm 0.5$ & $96.3 \pm 0.3$ & $100.6 \pm 13.4$ \\
\hline \multicolumn{5}{|l|}{ B } \\
\hline Treatment & CAVI & ENO2 & $\mathrm{PKC} \alpha$ & DHFR \\
\hline $\operatorname{siCAVI}+\operatorname{siENO} 2+\operatorname{siPKC} \alpha$ & $62.7 \pm 0.2$ & $44.20 \pm 0.9$ & $73.2 \pm 4.9$ & $97.7 \pm 8.8$ \\
\hline siCAVI + siENO2 + siPKC $\alpha+\operatorname{siDHFR}$ & $45.4 \pm 0.8$ & $36.34 \pm 4.2$ & $40.6 \pm 2.5$ & $33.4 \pm 3.8$ \\
\hline 400 nM NR-siRNA & $99.1 \pm 9.2$ & $100.57 \pm 15.9$ & $103.2 \pm 1.1$ & $95.5 \pm 10.2$ \\
\hline
\end{tabular}

Treatments combining the siRNAs against CAVI, ENO2 and PKC $\alpha$ at $100 \mathrm{nM}$ each were performed both in sensitive (A) and in resistant (B) HT29 cells. The mRNA levels for all three genes were determined at 48 hours of treatment. DHFR mRNA levels were also determined. Treatments combining $100 \mathrm{nM}$ of the previous three siRNAs plus a siRNA against DHFR were also performed in both cell lines and mRNA levels for the four genes quantified by RT-Real-Time PCR. A non-related (NR) siRNA was used as negative control. Results are expressed as percentages of mRNA referred to untreated cells (mean $\pm \mathrm{SE}$ ) of triplicate experiments.

Enolase 2 (ENO2) is induced by hypoxia, an intrinsic condition of tumors. Moreover, ENO2 is a glycolysis-related gene that has been described to play an important role in tumorogenesis of colorectal cancers [25]. Indeed, ENO2 is upregulated in a variety of cancers [26-28] and alpha-enolase is significantly upregulated in a metastasic colon cancer cell line, suggesting a possible association with the metastasic process in vitro and in vivo [29]. Indeed, we observed a notable contribution of ENO2 to MTX resistance when treating the sensitive cells with siENO2.

Both the $\alpha$-isozyme of PKC and caveolin 1 has been described to be associated with multidrug resistance $[30,31]$, and thus represent good targets to be analyzed. $\mathrm{PKC} \alpha$ phosphorylates different proteins, which triggers a wide variety of cellular responses including proliferation, differentiation, membrane transport, gene expression and tumor promotion $[32,33]$. Chemical inhibitors of PKC activity have been proposed as resistance modulators in MTX chemotherapy [34]. Furthermore, decreasing PKC $\alpha$ mRNA levels attenuates the MDR phenotype in tumor cells [35] and increases the sensitivity to anticancer drugs, both in vitro [36-38] and in vivo [39]. These observations are in accordance with our result showing that the decrease of PKC $\alpha$ mRNA levels by means of iRNA technology causes a sensitization of the cells toward MTX. Caveolin 1 (CAV1), the principal component of caveolae, has been associated with progression of colon and breast carcinomas [40,41] and with enhanced invasiveness in lung adenocarcinoma cells [42]. Although suggested as tumor suppressor gene, and downregulated in some oncogenetransformed and tumor-derived cells [31], overexpression of CAV1 has been found in prostate and esophageal cancer [43-45]. Moreover, re-expression of CAV1 at latter stages of tumor development has been described in human and mouse prostate adenocarcinomas [41], a scenario that could resemble chemotherapy resistance. Indeed, Bender et al. [46] found significantly higher levels of CAV1 in MTX resistant HT29 clones. We have confirmed the implication of CAV1 in MTX resistance in our HT29 cell line.

Nevertheless, as Benimetskaya and collaborators observed with PKC $\alpha$ [47], downregulation of a gene alone may be insufficient to completely chemosensitize the cells. Therefore, we considered a combination therapy in order to improve MTX sensitivity. As shown in figure 5, the combination of siRNAs against CAV1, ENO2 and PKC $\alpha$ sensitizes the cells toward MTX, and the effect is improved by the additional downregulation of DHFR. The effects of the triple or the quadruple combinations, however, are not the sum of the effects caused by each single siRNA. This probably reflects the difficulty of transfecting more than one siRNA at $100 \mathrm{nM}$ each. Indeed, the mRNA levels for the four genes after the combination treatment were not as reduced as with the single treatments. In the case of all treatments performed in the resistant cells, probably the overexpression by amplification of the dhfr locus was powerful enough to mask the effects of the siRNAs used.

Not only the overexpression of some genes may cause the resistance phenotype. One of the most underexpressed genes that we confirmed to be clearly lost in our HT29 MTX-resistant cells is E-cadherin. In fact, loss of E-cadherin, frequently observed in epithelial tumors, has been associated with tumor progression $[48,49]$ and is considered a crucial event that favors metastasis and invasiveness $[50,51]$. In addition, the mRNA levels of E-cadherin in 
A

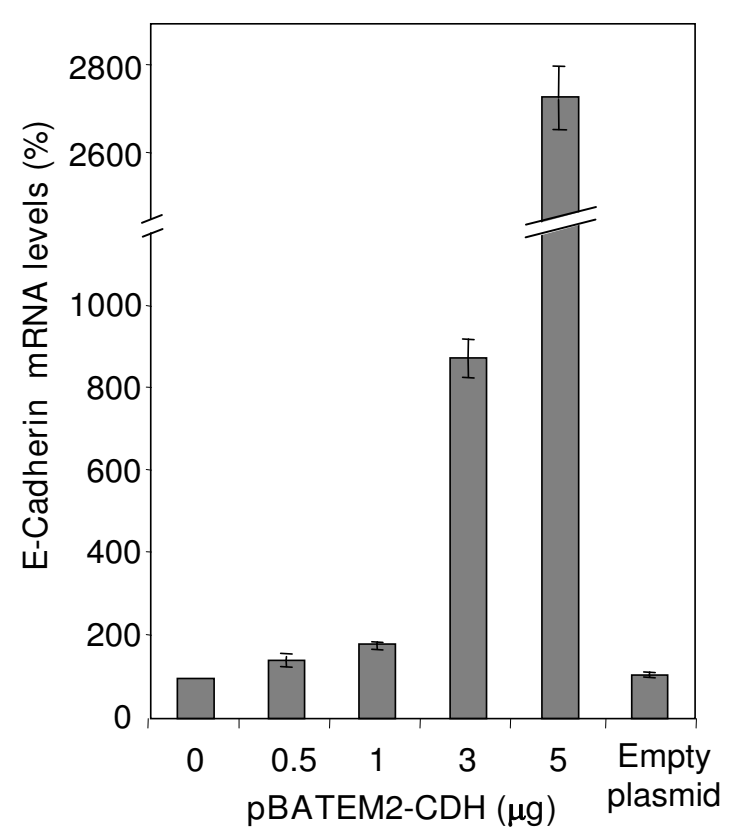

C

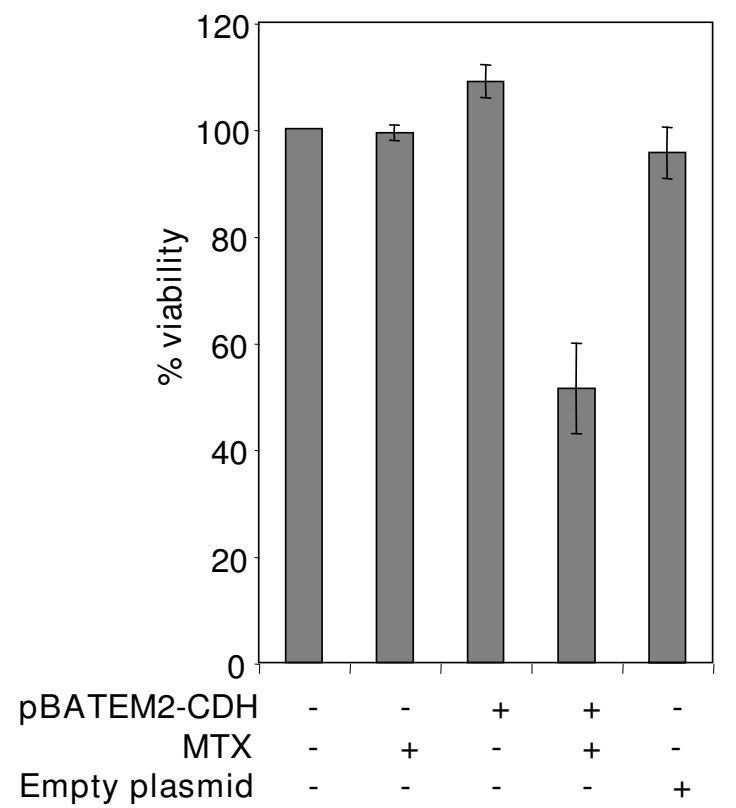

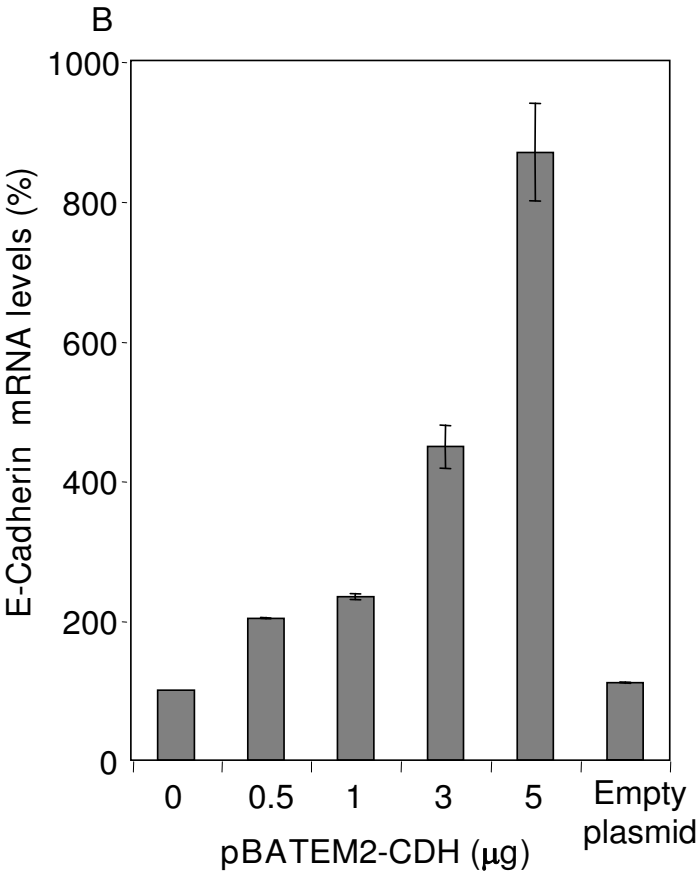

D

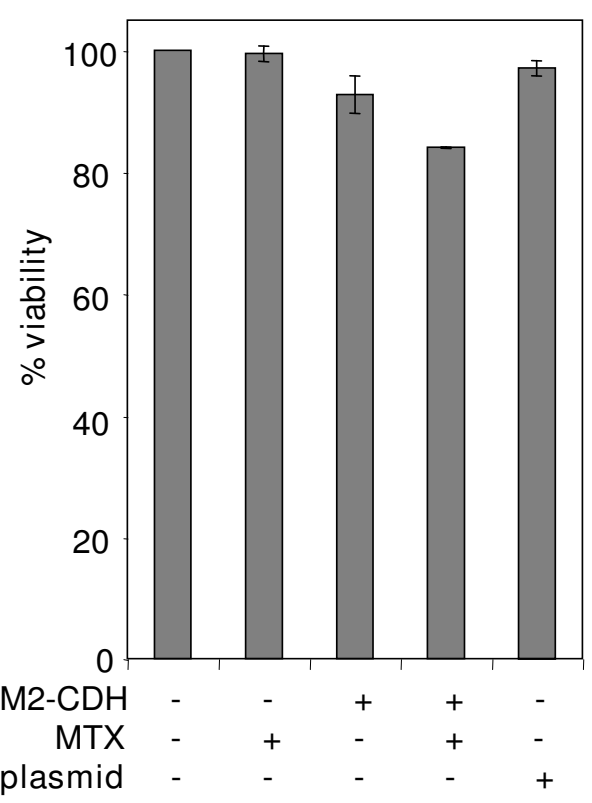

Figure 6

Determination of mRNA levels and cytotoxicity upon overexpression of E-cadherin. Cells were treated with increasing amounts of an expression plasmid encoding for E-cadherin (PBATEM2-CDH). Forty-eight hours after the treatment, mRNA levels were determined in HT29 sensitive (A) and MTX-resistant cells (B). Three independent experiments were performed and results are expressed as percentages referred to untreated cells. Values are the mean \pm SE. Simultaneous experiments of cells transfected with PBATEM2-CDH were treated with MTX $48 \mathrm{~h}$ after transfection, and viability of both sensitive (C) and MTX-resistant cells (D) was assessed after 5 days from the beginning of the treatment by the MTT assay. The mean value \pm SE of three independent experiments is depicted. An empty plasmid was used as negative control both for mRNA levels and cytotoxicity determination. 
Table 3: mRNA levels upon treatment with siCAVI and pBATEM2-CDH.

\begin{tabular}{cccc}
\hline Treatment & Cell line & CAVI & E-cadherin \\
\hline siCAVI + pBATEM2-CDH & HT29 sensitive & $21.8 \pm 1.9$ & $252.3 \pm 3.5$ \\
siCAVI + pBATEM2-CDH & HT29 resistant & $25.6 \pm 0.2$ & $199.7 \pm 16.9$ \\
\hline
\end{tabular}

Transfection experiments combining the siRNA against caveolin I (siCAVI) and the expression plasmid for E-cadherin (pBATEM2-CDH) were performed both in HT29 sensitive and MTX-resistant cells. Forty-eight hours later, mRNA levels for the two genes were determined in both cell lines by RT-Real-Time RCR. Results are expressed as percentages of mRNA referred to untreated cells (mean \pm SE) of at least 3 independent experiments.

adenocarcinoma are 2-fold lower than in normal colon cells [52]. Thus, there is a functional correlation between E-cadherin levels and malignancy. It has been described an event of loss of heterozygosity at the $16.1 \mathrm{q}$ chromosome band in most human prostate cancers, where E-cadherin is located [53], which is associated with tumor grade, advanced clinical stage and poor survival [54]. Our experiments show a decrease of 3-fold in E-cadherin levels in resistant cells and also that a mild overexpression of Ecadherin causes a higher sensitivity toward MTX. One has to be cautious, however, about the expression levels of Ecadherin since an increase of more than 3-fold in any of both cell lines caused a reduction in cell viability. This is in accordance with the experiments of Derksen et al. [55] that suggested that loss of E-cadherin could play a causal role in the acquisition of anoikis resistance, as parental mammary cells lacking E-cadherin survived while reexpression of the gene caused apoptosis [55]. Previous works show that loss of E-cadherin in either skin or mammary epithelium does not induce tumor formation [55]. Thus, an overall view of the events occurring in our HT29 cells resistant to methotrexate is needed.

It has been shown that activated PKC $\alpha$ translocates from the nucleus to the membrane [56], where it associates with caveolae $[57,58]$, and regulates the function and formation of such biological structures. PKC $\alpha$ has been described to directly interact with CAV1. The union is performed between the caveolin 1 scaffolding domain peptide and PKC $\alpha$ caveolin 1 binding motif [59]. Further, activation of PKC $\alpha$ by phorbol esters dislocates the enzyme from caveolae. All these observations indicate that PKC $\alpha$ interacts functionally with this membrane structures. Moreover, PKC $\alpha$ has been proposed to be involved in the rearrangement of the cytoskeleton. Masur et al. showed that a high level of PKC $\alpha$ expression plus a low E-cadherin level predicts an elevated migratory activity of colon carcinoma cells, which could be derived more easily to metastasis [56]. Lahn et al. speculate that PKC $\alpha$ overexpression may represent an important cellular event leading to enhanced tumor progression, as they concluded that MCF-7 breast cancer cells transfected with PKC $\alpha$ had reduced expression of E-cadherin and $\beta$-catenin, resulting in a loss of cell-cell adhesion and thus in a more aggressive tumor phenotype [38].
Specific protein-protein interactions between CAV1 and other proteins have been proposed to regulate cell signaling $[57,60]$. Indeed, CAV1 is known to control cell proliferation and viability by inhibiting expression of survivin, a member of the IAP (inhibitor of apoptosis) family via a transcriptional mechanism involving the $\beta$-catenin-Tcf/ Lef-1 pathway [16]. One of the possible locations of $\beta$-catenin is within a complex with E-cadherin in the adherence junctions, specialized cell-cell adhesion sites that link the cadherin molecules to the actin microfilaments [61]. Ecadherin promotes co-localization and co-imunoprecipitation of CAV1 with $\beta$-catenin, as well as inhibition of $\beta$ catenin-Tcf/Lef-1 dependent transcription of a wide variety of genes regulated by this pathway, among which survivin is found. However, the ability of CAV1 to regulate survivin expression and cell proliferation is severely impaired in metastasic cancer cells lacking E-cadherin [16]. If E-cadherin is lost, $\beta$-catenin is not retained in the plasma membrane and can be then translocated into the nucleus [62], thus activating Tcf/Lef-1 transcription factors-mediated expression of genes implicated in cell proliferation and tumor progression [50]. E-cadherin has been shown to be an important permissive element in defining the functions of CAV1, since several characteristics potentially relevant to CAV1 function as a tumor suppressor are compromised in E-cadherin-deficient HT29 cells [16]. A diagram showing all these relations is presented in Figure 8.

Our results show that HT29 cells can be well sensitized toward MTX by simultaneous treatment with siCAV1 and pBATEM2-CDH. Importantly, we can revert the resistant scenario by reducing the levels of caveolin 1 and by overexpressing E-cadherin simultaneously in the resistant cells, demonstrating the roles that play both genes in MTX resistance.

\section{Conclusion}

We demonstrate that, aside from $d h f r$, the contribution of the $5 \mathrm{q} 14$ co-amplified genes to MTX resistance is small in HT29 colon cancer cells. On the other hand, we have identified genes deregulated in MTX resistant cells and have demonstrated a role for caveolin 1, E-cadherin, enolase 2 and PKC $\alpha$ in MTX resistance. Very importantly, the concomitant knocking down of CAV1 with overexpres- 

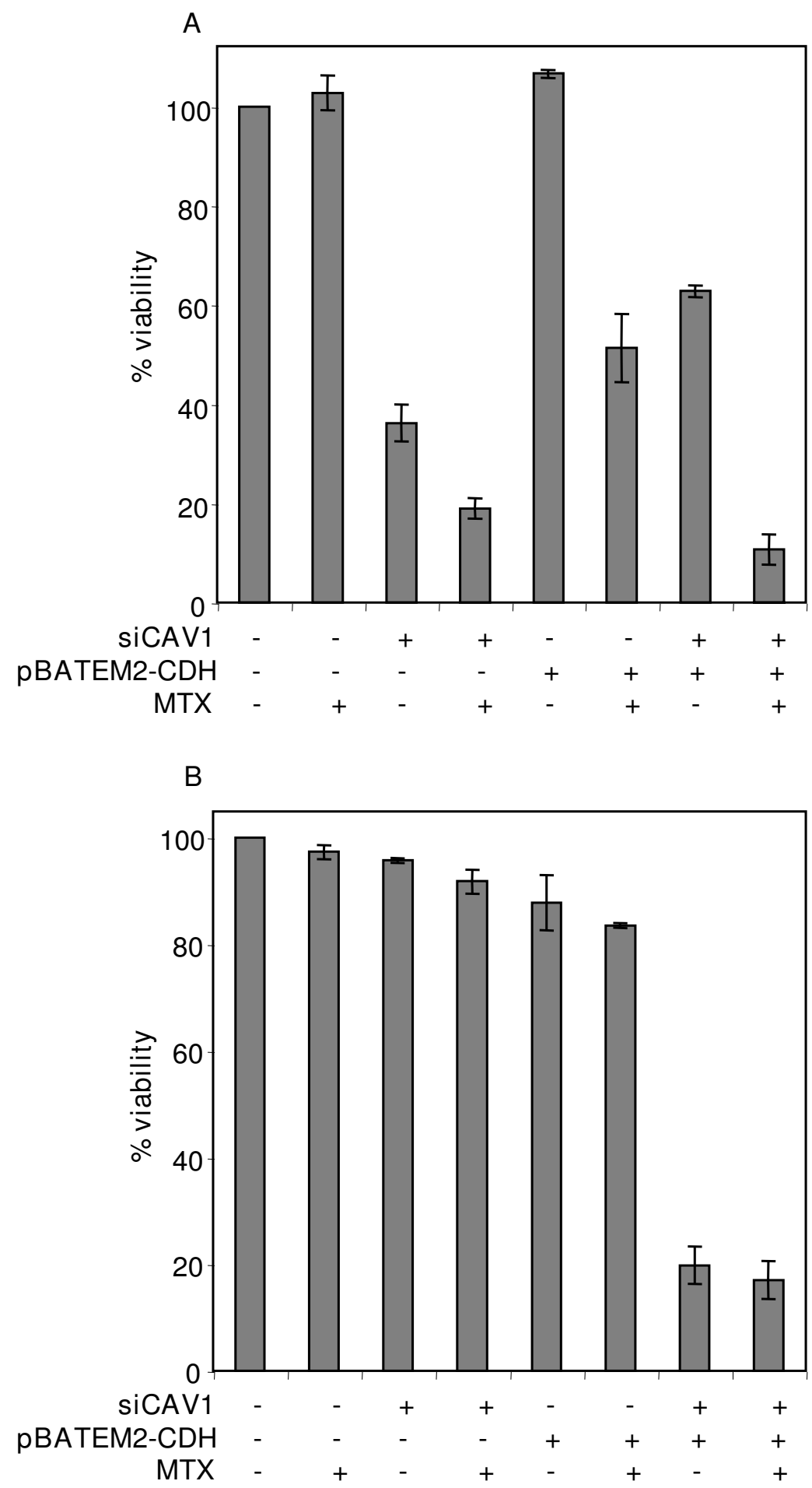

Figure 7

Effect of combining the siRNA against CAVI and the expression plasmid for E-cadherin. One hundred nanomolar siRNA against CAVI and I $\mu$ g of the expression plasmid for E-cadherin were transfected in both sensitive (A) and resistant (B) HT29 cells. MTX was added 48 hours after transfection and the MTT assay was used to determine cell viability. Results are expressed as percentages referred to untreated cells. Values are the mean of three independent experiments \pm SE. 


\section{SENSITIVE CELLS}

\section{(E-Cadherin PRESENT )}

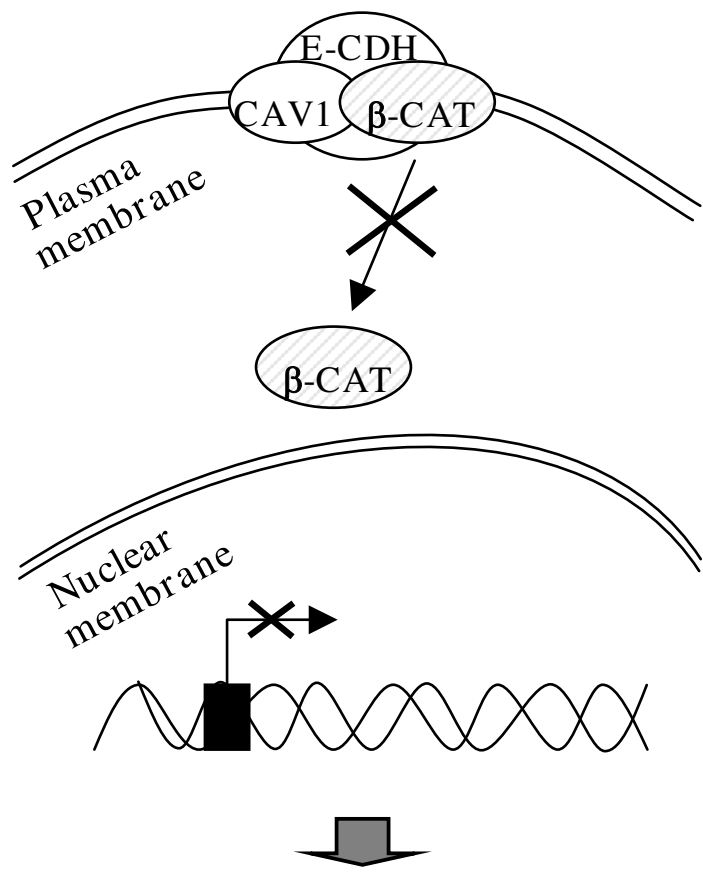

Decreased Growth

\section{MTX-RESISTANT CELLS}

\author{
( E-Cadherin LOST )
}

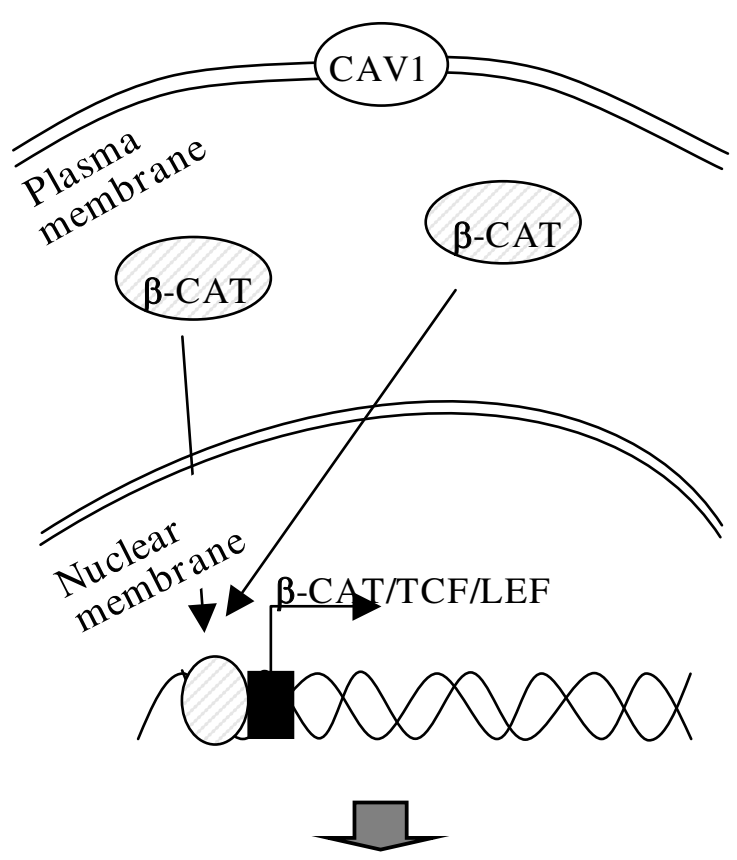

Increased Growth

Figure 8

Scheme for HT29 sensitive and MTX-resistant cells. A diagram is presented showing the compartment localization of CAVI, E-cadherin (E-CDH) and $\beta$-catenin ( $\beta$-CAT) in HT29 sensitive cells (with E-cadherin) and MTX-resistant cells (without E-cadherin, gene loss) and the effects caused by this differential situation. In the sensitive cells, $\beta$-catenin is located in the adherence junctions within a complex with E-cadherin. CAVI co-localizes with $\beta$-catenin in these complexes, interfering in $\beta$-CAT signaling. If $E$-cadherin is lost, as in the resistant cells, $\beta$-catenin is not retained in the plasma membrane and then can be translocated into the nucleus, thus activating Tcf/Lef-I transcription factors-mediated expression of genes implicated in cell proliferation and tumor progression.

sion of E-cadherin in HT29 resistant cells markedly reduced cell viability.

\section{Competing interests}

The authors declare that they have no competing interests.

\section{Authors' contributions}

ES carried out the siRNA and plasmid transfections, the determination of mRNA levels and associated cytotoxicity after these treatments, and drafted the manuscript. CM carried out the mRNA levels validations, the copy number determinations and helped to draft the manuscript. VN helped with data interpretation and to draft the manuscript, critically revising it. MAP participated in the design of the study and in its coordination, and helped to revise the manuscript. CJC conceived the study, participated in microarray data analyses and drafted the manuscript. All authors read and approved the final manuscript. 


\section{Additional material}

\section{Additional file 1}

Table of genes differentially expressed by 3 fold. Excel file containing the list of 3-fold differentially expressed genes generated using GeneSpring software $v$ 7.3.1. It includes the GenBank numbers of all genes, their respective common names and the associated description. The chromosomal localization of the 375 entries and the fold change values relative to the control are provided. A final column informing about one of the Gene Ontology categories to which the genes belong according to GeneSpring is included. The differentially expressed transcripts corresponding to open reading frames, transcribed sequences, cDNA clones or hypothetical genes were deleted.

Click here for file

[http://www.biomedcentral.com/content/supplementary/17558794-1-35-S1.xls]

\section{Additional file 2}

Primers used to validate mRNA levels of selected genes. PDF file with sequences for the primers used to quantify the mRNA levels of genes studied, next to their common name and the number of the chromosome where they are located.

Click here for file

[http://www.biomedcentral.com/content/supplementary/17558794-1-35-S2.pdf]

\section{Additional file 3}

Primers used to determine the copy-number of selected genes. PDF file with common names, chromosome number and the sequences of primers used to amplify their respective DNAs for all selected genes.

Click here for file

[http://www.biomedcentral.com/content/supplementary/17558794-1-35-S3.pdf]

\section{Additional file 4}

Sequences for the sense strand of all siRNAs used. PDF file where the sequences for the sense strand of all the siRNAs used are provided next to the names used to designate all them and the genes they are directed against.

Click here for file

[http://www.biomedcentral.com/content/supplementary/17558794-1-35-S4.pdf]

\section{Acknowledgements}

This work was supported by grants SAF05-247 and SAF08-00043 to CJC and SAF06-35I to MAP, all from "Plan Nacional de I+D+l", and ISCIIIRETIC RD06/0020. Our research group holds the "quality distinction" from the "Generalitat de Catalunya" SGR05-0883. E.S. is a recipient of a fellowship from the Ministerio de Ciencia y Tecnología (MCYT).

PBATEM2-CDH was kindly provided by Dr. Duñach, Universitat Autonoma de Barcelona, Barcelona, Spain.

\section{References}

I. World Health Organization [http://www.who.int]

2. Morales C, Ribas M, Aiza G, Peinado MA: Genetic determinants of methotrexate responsiveness and resistance in colon cancer cells. Oncogene 2005, 24:6842-7.

3. Heppner $\mathrm{GH}$, Miller FR: The cellular basis of tumor progression. Int Rev Cytol 1998, 177:1-56.
4. Chen MJ, Shimada T, Moulton AD, Cline A, Humphries RK, Maizel J, Nienhuis $A W$ : The functional human dihydrofolate reductase gene. J Biol Chem 1984, 259:3933-43.

5. Chu E, Grem JL, Johnston PG, Allegra CJ: New concepts for the development and use of antifolates. Stem Cells 1996, I4:4I-6.

6. Guglielmi A, Barni S, Zaniboni A, Pella N, Belvedere O, Beretta GD, Grossi F, Frontini L, Puglisi F, Labianca R, Sobrero A: Phase II study of a triplet regimen in advanced colorectal cancer using methotrexate, oxaliplatin and 5-fluorouracil. Br J Cancer 2004, 91:1428-33.

7. Sobrero A, Frassineti G, Falcone A, Dogliotti L, Rosso R, Di Costanzo F, Bruzzi P: Adjuvant sequential methotrexate --> 5-fluorouracil vs 5-fluorouracil plus leucovorin in radically resected stage III and high-risk stage II colon cancer. Br J Cancer 2005, 92:24-9.

8. Zampino MG, Lorizzo K, Rocca A, Locatelli M, Zorzino L, Manzoni S, Mazzetta C, Fazio N, Biffi R, De Braud F: Oxaliplatin combined with 5-fluorouracil and methotrexate in advanced colorectal cancer. Anticancer Res 2006, 26:2425-8.

9. Albertson DG, Collins C, McCormick F, Gray JW: Chromosome aberrations in solid tumors. Nat Genet 2003, 34:369-76.

10. Singer MJ, Mesner LD, Friedman CL, Trask BJ, Hamlin JL: Amplification of the human dihydrofolate reductase gene via double minutes is initiated by chromosome breaks. Proc Natl Acad Sci USA 2000, 97:792I-6.

II. Rots MG, Pieters R, Kaspers G], Veerman AJ, Peters G], Jansen G: Classification of ex vivo methotrexate resistance in acute lymphoblastic and myeloid leukaemia. Br J Haematol 2000, I 1 0:79|-800.

12. Selga $E$, Noe $V$, Ciudad $C$ J: Transcriptional regulation of aldoketo reductase ICI in HT29 human colon cancer cells resistant to methotrexate: role in the cell cycle and apoptosis. Biochem Pharmacol 2008, 75:414-26.

13. Gene Expression Omnibus [http://www.ncbi.nlm.nih.gov/geo/]

14. Rocke DM, Durbin B: A model for measurement error for gene expression arrays. J Comput Biol 200I, 8:557-69.

15. Mosmann T: Rapid colorimetric assay for cellular growth and survival: application to proliferation and cytotoxicity assays. J Immunol Methods 1983, 65:55-63.

16. Torres VA, Tapia JC, Rodriguez DA, Lladser A, Arredondo C, Leyton L, Quest AF: E-cadherin is required for caveolin-I-mediated down-regulation of the inhibitor of apoptosis protein survivin via reduced beta-catenin-Tcf/Lef-dependent transcription. Mol Cell Biol 2007, 27:7703-17.

17. Drummond JT, Genschel J, Wolf E, Modrich P: DHFR/MSH3 amplification in methotrexate-resistant cells alters the hMutSal$\mathrm{pha} / \mathrm{hMutSbeta}$ ratio and reduces the efficiency of base-base mismatch repair. Proc Natl Acad Sci USA 1997, 94:10144-9.

18. Pandit B, Roy M, Dutta J, Padhi BK, Bhoumik G, Bhattacharyya NP: Co-amplification of dhfr and a homologue of hmsh3 in a Chinese hamster methotrexate-resistant cell line correlates with resistance to a range of chemotherapeutic drugs. Cancer Chemother Pharmacol 200I, 48:312-8.

19. Jones KR, Gewirtz DA, Yannone SM, Zhou S, Schatz DG, Valerie K, Povirk LF: Radiosensitization of MDA-MB-23 I breast tumor cells by adenovirus-mediated overexpression of a fragment of the XRCC4 protein. Mol Cancer Ther 2005, 4:I54I-7.

20. Arozarena I, Matallanas D, Berciano MT, Sanz-Moreno V, Calvo F, Munoz MT, Egea G, Lafarga M, Crespo P: Activation of H-Ras in the endoplasmic reticulum by the RasGRF family guanine nucleotide exchange factors. Mol Cell Biol 2004, 24:1516-30.

21. Malumbres M, Pellicer A: RAS pathways to cell cycle control and cell transformation. Front Biosci 1998, 3:d887-912.

22. Liang H, Samanta S, Nagarajan L: SSBP2, a candidate tumor suppressor gene, induces growth arrest and differentiation of myeloid leukemia cells. Oncogene 2005, 24:2625-34

23. Rezaee M, Penta K, Quertermous T: Dell mediates VSMC adhesion, migration, and proliferation through interaction with integrin alpha(v)beta(3). Am J Physiol Heart Circ Physiol 2002, 282: $\mathrm{H} 1924-32$

24. Petitclerc E, Stromblad S, von Schalscha TL, Mitjans F, Piulats J, Montgomery AM, Cheresh DA, Brooks PC: Integrin alpha(v)beta3 promotes $\mathrm{M} 2 \mathrm{I}$ melanoma growth in human skin by regulating tumor cell survival. Cancer Res 1999, 59:2724-30.

25. Yeh CS, Wang JY, Chung FY, Lee SC, Huang MY, Kuo CW, Yang MJ, Lin SR: Significance of the glycolytic pathway and glycolysis 
related-genes in tumorigenesis of human colorectal cancers. Oncol Rep 2008, 19:8I-91.

26. Karnak D, Beder S, Kayacan O, Ibis E, Oflaz G: Neuron-specific enolase and lung cancer. Am J Clin Oncol 2005, 28:586-90.

27. Fujiwara $\mathrm{H}$, Arima N, Ohtsubo H, Matsumoto T, Kukita T, Kawada H, Imaizumi R, Ozaki A, Matsushita K, Tei C: Clinical significance of serum neuron-specific enolase in patients with adult T-cell leukemia. Am J Hematol 2002, $71: 80-4$.

28. Kitakata $\mathrm{H}$, Yasumoto $\mathrm{K}$, Sudo $\mathrm{Y}$, Minato $\mathrm{H}$, Takahashi $\mathrm{Y}$ : A case of primary small cell carcinoma of the breast. Breast Cancer 2007, 14:4|4-9.

29. Katayama M, Nakano H, Ishiuchi A, Wu W, Oshima R, Sakurai J, Nishikawa $\mathrm{H}$, Yamaguchi S, Otsubo T: Protein pattern difference in the colon cancer cell lines examined by two-dimensional differential in-gel electrophoresis and mass spectrometry. Surg Today 2006, 36:1085-93.

30. Yu G, Ahmad S, Aquino A, Fairchild CR, Trepel JB, Ohno S, Suzuki K Tsuruo T, Cowan $\mathrm{KH}$, Glazer RI: Transfection with protein kinase $C$ alpha confers increased multidrug resistance to MCF-7 cells expressing P-glycoprotein. Cancer Commun 199I, 3:181-9.

31. Lavie Y, Fiucci G, Liscovitch M: Up-regulation of caveolae and caveolar constituents in multidrug-resistant cancer cells. J Biol Chem 1998, 273:32380-3.

32. Martelli AM, Sang N, Borgatti P, Capitani S, Neri LM: Multiple biological responses activated by nuclear protein kinase $\mathrm{C}$. J Cell Biochem 1999, 74:499-52I.

33. Wang XY, Repasky E, Liu HT: Antisense inhibition of protein kinase Calpha reverses the transformed phenotype in human lung carcinoma cells. Exp Cell Res 1999, 250:253-63.

34. Noe V, Ciudad C]: Protein kinase $\mathbf{C}$ inhibitors reduce phorbol ester-induced resistance to methotrexate in Chinese hamster ovary cells. Biochem Pharmacol 1995, 50:337-46.

35. Ahmad S, Glazer RI: Expression of the antisense cDNA for protein kinase $C$ alpha attenuates resistance in doxorubicinresistant MCF-7 breast carcinoma cells. Mol Pharmacol 1993 43:858-62.

36. Wang $X Y$, Liu HT: Antisense expression of protein kinase $\mathbf{C}$ alpha improved sensitivity to anticancer drugs in human lung cancer LTEPa-2 cells. Zhongguo Yao Li Xue Bao 1998, 19:265-8.

37. Isonishi S, Ohkawa K, Tanaka T, Howell SB: Depletion of protein kinase C (PKC) by 12-O-tetradecanoylphorbol-13-acetate (TPA) enhances platinum drug sensitivity in human ovarian carcinoma cells. $\mathrm{Br} J$ Cancer 2000, 82:34-8.

38. Lahn M, Kohler G, Sundell K, Su C, Li S, Paterson BM, Bumol TF: Protein kinase $C$ alpha expression in breast and ovarian cancer. Oncology 2004, 67:1-10.

39. Geiger T, Muller M, Dean NM, Fabbro D: Antitumor activity of a PKC-alpha antisense oligonucleotide in combination with standard chemotherapeutic agents against various human tumors transplanted into nude mice. Anticancer Drug Des 1998, 13:35-45.

40. Thompson TC: Metastasis-related genes in prostate cancer: the role of caveolin-I. Cancer Metastasis Rev 1998, I7:439-42.

4I. Yang G, Truong LD, Timme TL, Ren C, Wheeler TM, Park SH, Nasu Y, Bangma CH, Kattan MW, Scardino PT, Thompson TC: Elevated expression of caveolin is associated with prostate and breast cancer. Clin Cancer Res 1998, 4:1873-80.

42. Ho CC, Huang PH, Huang HY, Chen YH, Yang PC, Hsu SM: Up-regulated caveolin-I accentuates the metastasis capability of lung adenocarcinoma by inducing filopodia formation. Am J Pathol 2002, 16I:1647-56.

43. Li L, Yang G, Ebara S, Satoh T, Nasu Y, Timme TL, Ren C, Wang J, Tahir SA, Thompson TC: Caveolin-I mediates testosteronestimulated survival/clonal growth and promotes metastatic activities in prostate cancer cells. Cancer Res 200I, 61:4386-92.

44. Kato K, Hida Y, Miyamoto M, Hashida H, Shinohara T, Itoh T, Okushiba $\mathrm{S}$, Kondo $\mathrm{S}$, Katoh $\mathrm{H}$ : Overexpression of caveolin-I in esophageal squamous cell carcinoma correlates with lymph node metastasis and pathologic stage. Cancer 2002, 94:929-33.

45. Mouraviev V, Li L, Tahir SA, Yang G, Timme TM, Goltsov A, Ren C, Satoh T, Wheeler TM, Ittmann MM, Miles BJ, Amato RJ, Kadmon D, Thompson TC: The role of caveolin-I in androgen insensitive prostate cancer. J Urol 2002, I68:1589-96.

46. Bender FC, Reymond MA, Bron C, Quest AF: Caveolin-I levels are down-regulated in human colon tumors, and ectopic expres- sion of caveolin-I in colon carcinoma cell lines reduces cell tumorigenicity. Cancer Res 2000, 60:5870-8.

47. Benimetskaya L, Miller P, Benimetsky S, Maciaszek A, Guga P, Beaucage SL, Wilk A, Grajkowski A, Halperin AL, Stein CA: Inhibition of potentially anti-apoptotic proteins by antisense protein kinase C-alpha (Isis 352I) and antisense bcl-2 (G3I39) phosphorothioate oligodeoxynucleotides: relationship to the decreased viability of T24 bladder and PC3 prostate cancer cells. Mol Pharmacol 200I, 60:I296-307.

48. Behrens J, Mareel MM, Van Roy FM, Birchmeier W: Dissecting tumor cell invasion: epithelial cells acquire invasive properties after the loss of uvomorulin-mediated cell-cell adhesion. J Cell Biol 1989, 108:2435-47.

49. Perl AK, Wilgenbus P, Dahl U, Semb H, Christofori G: A causal role for E-cadherin in the transition from adenoma to carcinoma. Nature 1998, 392:190-3.

50. Cavallaro U, Christofori G: Cell adhesion and signalling by cadherins and Ig-CAMs in cancer. Nat Rev Cancer 2004, 4: I I 8-32.

5I. Frixen UH, Behrens J, Sachs M, Eberle G, Voss B, Warda A, Lochner $D$, Birchmeier W: E-cadherin-mediated cell-cell adhesion prevents invasiveness of human carcinoma cells. J Cell Biol I99I, I 1 3:173-85.

52. Munro SB, Turner IM, Farookhi R, Blaschuk OW, Jothy S: E-cadherin and OB-cadherin mRNA levels in normal human colon and colon carcinoma. Exp Mol Pathol 1995, 62: I 18-22.

53. Suzuki H, Komiya A, Emi M, Kuramochi H, Shiraishi T, Yatani R, Shimazaki J: Three distinct commonly deleted regions of chromosome arm I6q in human primary and metastatic prostate cancers. Genes Chromosomes Cancer 1996, 17:225-33.

54. Cheng L, Nagabhushan M, Pretlow TP, Amini SB, Pretlow TG: Expression of E-cadherin in primary and metastatic prostate cancer. Am J Pathol I996, I48:1375-80.

55. Derksen PW, Liu X, Saridin F, Gulden H van der, Zevenhoven J, Evers B, van Beijnum JR, Griffioen AW, Vink J, Krimpenfort P, Peterse JL, Cardiff RD, Berns A, Jonkers J: Somatic inactivation of E-cadherin and p53 in mice leads to metastatic lobular mammary carcinoma through induction of anoikis resistance and angiogenesis. Cancer Cell 2006, 10:437-49.

56. Masur K, Lang K, Niggemann B, Zanker KS, Entschladen F: High PKC alpha and low E-cadherin expression contribute to high migratory activity of colon carcinoma cells. Mol Biol Cell 200I, 1 2:1973-82.

57. Lisanti MP, Scherer PE, Vidugiriene J, Tang Z, Hermanowski-Vosatka A, Tu YH, Cook RF, Sargiacomo M: Characterization of caveolinrich membrane domains isolated from an endothelial-rich source: implications for human disease. J Cell Biol 1994, 126: I II-26.

58. Liu P, Rudick M, Anderson RG: Multiple functions of caveolin- I. J Biol Chem 2002, 277:4I 295-8.

59. Oka N, Yamamoto M, Schwencke C, Kawabe J, Ebina T, Ohno S, Couet J, Lisanti MP, Ishikawa Y: Caveolin interaction with protein kinase $C$. Isoenzyme-dependent regulation of kinase activity by the caveolin scaffolding domain peptide. I Biol Chem 1997, 272:334I6-2I.

60. Okamoto T, Schlegel A, Scherer PE, Lisanti MP: Caveolins, a family of scaffolding proteins for organizing "preassembled signaling complexes" at the plasma membrane. J Biol Chem 1998, 273:5419-22.

61. Okegawa T, Pong RC, Li Y, Hsieh JT: The role of cell adhesion molecule in cancer progression and its application in cancer therapy. Acta Biochim Pol 2004, 5 I :445-57.

62. Brabletz T, Jung A, Reu S, Porzner M, Hlubek F, Kunz-Schughart LA Knuechel R, Kirchner T: Variable beta-catenin expression in colorectal cancers indicates tumor progression driven by the tumor environment. Proc Natl Acad Sci USA 200I, 98: I0356-6I.

\section{Pre-publication history}

The pre-publication history for this paper can be accessed here:

http://www.biomedcentral.com/1755-8794/1/35/prepub 